\title{
Physiological Characteristics and Production of Folic Acid of Lactobacillus plantarum JA71 Isolated from Jeotgal, a Traditional Korean Fermented Seafood
}

\author{
Sun-Young Park, Jeong-Ryong Do, Young-Jin Kim, Kee-Sung Kim, and Sang-Dong Lim* \\ Korea Food Research Institute, Seongnam 463-746, Korea
}

\begin{abstract}
Folic acid, one of the B group of vitamins, is an essential substance for maintaining the functions of the nervous system, and is also known to decrease the level of homocysteine in plasma. Homocysteine influences the lowering of the cognitive function in humans, and especially in elderly people. In order to determine the strains with a strong capacity to produce folic acid, 190 bacteria were isolated from various kinds of jeotgal and chungkuk-jang. In our test experiment, JA71 was found to contain $9.03 \mu \mathrm{g} / \mathrm{mL}$ of folic acid after $24 \mathrm{~h}$ of incubation in an MRS broth. This showed that JA71 has the highest folic acid production ability compared to the other lactic acid bacteria that were isolated. JA71 was identified as Lactobacillus plantarum by the result of API carbohydrate fermentation pattern and 16s rDNA sequence. JA71 was investigated for its physiological characteristics. The optimum growth temperature of JA71 was $37^{\circ} \mathrm{C}$, and the cultures took $12 \mathrm{~h}$ to reach $\mathrm{pH}$ 4.4. JA71 proved more sensitive to bacitracin when compared with fifteen different antibiotics, and showed most resistance to neomycin and vancomycin. Moreover, it was comparatively tolerant of bile juice and acid, and displayed resistance to Escherichia coli, Salmonella Typhimurium, and Staphylococcus aureus with restraint rates of 60.4\%, 96.7\%, and 76.2\%, respectively. These results demonstrate that JA71 could be an excellent strain for application to functional products.
\end{abstract}

Key words: Lactobacillus plantarum, physiological characteristics, folic acid, functional product

\section{Introduction}

In recent times, the cognitive function in humans, from children to the elderly, has become an important subject of interest. Known as folate in its natural form, folic acid belongs to the B group of vitamins, and is a very important substance in maintaining the functions of the central nervous system in human beings along with certain other B-group vitamins such as vitamin $B_{2}$, vitamin $B_{6}$, and vitamin $B_{12}$ (Duthie et al., 2002). A deficient intake of the $B$ vitamins involved in the single-carbon metabolism can lead to the development of hyperhomocysteinemia; and an increased level of homocysteine has been reported not only to be a risk factor with regard to vascular diseases but also to cause DNA damage to the central nervous system (Kim et al., 2011; Kruman et al., 2000). In addition to the relationship between the intake and blood level of B-group vitamins (including folic acid) and the cognitive functions, it has been also reported that a decrease in

*Corresponding author: Sang-Dong Lim, Korea Food Research Institute, Seongnam 463-746, Korea. Tel: 82-31-780-9082, Fax: 82-31-780-9160, E-mail: limsd@kfri.re.kr homocysteine in the blood caused by vitamin B group supplementation improved the cognitive functions (Dangour et al., 2010; McMahon et al., 2006; Morris et al., 2005; Riggs et al., 1996).

Jeotgal, which is a highly representative traditional Korean dish made of fish and shellfish, is a fermented food made by several kinds of microbes and enzymatic actions (Kim et al., 1996). Jeotgal usually has halophilic or halotolerant aerobic and anaerobic bacteria; the microbes involved in the fermentation and maturing of jeotgal include such bacteria as Lactobacillus genus, Flavobacterium genus Micrococcus genus, Bacillus genus, Arevibacterium genus, Leuconostoc genus, and Pseudomonas genus, and a variety of yeasts (Hur, 1996). Among the microbes in jeotgal, lactic acid bacteria are particularly helpful in preventing diseases due to their anti-cancer action, anti-oxidative, immune activation and cholesterol-lowering actions (Cotter et al., 2005). According to the results of several studies, it has been reported that certain lactic acid bacteria contain folic acids that help improve the cognitive functions (Divya et al., 2012; Lin and Young, 2000).

Thus, this study was performed to investigate the phys- 
iological characteristics of $L$. plantarum JA71 having excellent folic acid activity, which was selected from among lactic acid bacteria isolated from traditional Korean fermented foods, and to determine its potential as a starter for functional fermented milk products.

\section{Materials and Methods}

\section{Isolation of lactic acid bacteria}

Various kinds of home-made and domestic jeotgal and chungkuk-jang products were collected. Strain JA71 was isolated from jeotgal in the modified MRS medium. The strain was incubated in Lactobacilli MRS broth (Difco, USA) as the growth medium at $37^{\circ} \mathrm{C}$ for $18 \mathrm{~h}$.

\section{HPLC analysis of extracellular folic acid produc- tion Standard}

Folic acid (Sigma, USA) was used as the standard and sodium bicarbonate (Sigma) was used as the solvent of folic acid.

\section{HPLC analysis}

An analysis of extracellular folic acid was performed using a JASCO LC-2000 series HPLC system (JASCO, Japan) equipped with a PU-2089 quaternary gradient pump, an AS-2051 auto-sampler, a MD-2018 diode array detector (DAD), a CO-2060 column temperature control compartment, a FP-2020 fluorescence detector, and an LC-Net II/ADC data collector. Chromatographic data were acquired and processed with the computer-based ChromNAV software (JASCO, Japan). The operating conditions were as follows: column temperature, $28^{\circ} \mathrm{C}$; flow rate, $0.5 \mathrm{~mL} / \mathrm{min}$; injection volume: $10 \mu \mathrm{L}$; UVdetection at $282 \mathrm{~nm}$. Chromatographic separations were performed on a Capcell pack MF $\mathrm{C}_{18}$ column $(5.0 \mu \mathrm{m}$ particle size, $150 \times 4.6 \mathrm{~mm}$ i.d.; Shiseido, Tokyo, Japan), and the mobile phase consisted of $50 \mathrm{mM}$ Phosphate buffer:acetonitrile $(85: 15, \mathrm{v} / \mathrm{v})$. Prior to the HPLC analysis, all samples were filtered through a $0.45 \mu \mathrm{m}$ Ad- vantec filter.

\section{Identification of strain JA71}

The properties of the strain JA71 were investigated by testing the Gram staining and microscopic observation after cultivation on Tryptic soy agar (Difco) for $24 \mathrm{~h}$ at $37^{\circ} \mathrm{C}$. Bergey's Manual of Systematic Bacteriology by Buchanan and Gibbons (1974) was used to examine the morphological and physiological properties of the isolated strains. The JA71 strain was identified by using the
16S rDNA sequencing method. The chromosomal DNA of the isolated strain was separated by using the SolGent Genomic DNA prep kit (SolGent, Korea). The DNA extracts were used for the polymerase chain reaction (PCR) with the universal primers [27F (5'-AGA GTT TGA TCC TGG CTC AG-3') and 1492R (5'-GGT TAC CTT GTT ACG ACT T-3')]. PCR was carried out in a programmable therma cycler (SolGent EF-Taq, Korea), according to the following steps: one cycle of denaturation at $95^{\circ} \mathrm{C}$ for $15 \mathrm{~min}$, followed by 30 cycles of $95^{\circ} \mathrm{C}$ for $20 \mathrm{~s}, 50^{\circ} \mathrm{C}$ for $40 \mathrm{~s}$, and $72^{\circ} \mathrm{C}$ for $90 \mathrm{~s}$. The final extension was carried out at $72^{\circ} \mathrm{C}$ for $5 \mathrm{~min}$. The purified PCR product obtained by using a SolGent PCR purification kit (SolGent, Korea) was used for sequencing with a ABI 3730XL DNA analyzer (Applied Biosystems, USA).

\section{Growth of strain}

The number of viable L. plantarum JA71 was determined by serial ten-fold dilution in $0.1 \%$ peptone water. $10 \mu \mathrm{L}\left(9.6 \times 10^{5} / \mathrm{mL}\right)$ L. plantarum JA71 was inoculated into $150 \mathrm{~mL}$ of MRS broth; then the culture was incubated at $3 \mathrm{~h}$ intervals until $24 \mathrm{~h}$ at $34^{\circ} \mathrm{C}, 37^{\circ} \mathrm{C}$ and $40^{\circ} \mathrm{C}$. All pour plates were incubated aerobically at $37^{\circ} \mathrm{C}$ for $48 \mathrm{~h}$ using the BCP plate count agar (Eiken, Japan).

\section{Antibiotic tolerance}

L. plantarum JA71 was grown at $37^{\circ} \mathrm{C}$ for $18 \mathrm{~h}$ in MRS broth and inoculated $(1 \%, \mathrm{v} / \mathrm{v})$ into Tryptic soy broth (Difco) supplemented with antibiotics (amikacin, gentamicin, kanamycin, neomycin, streptomycin, penicillin-G, methicillin, oxacillin, ampicillin, bacitracin, rifampicin, novobiocin, lincomycin, polymyxin $\mathrm{B}$, and chloramphenico; Sigma) at various concentrations in a two-fold dilution step. The minimal inhibitory concentration (MIC) was determined by checking the moment at which the strain stopped growing after incubation at $37^{\circ} \mathrm{C}$ for $48 \mathrm{~h}$.

\section{Enzyme activity}

The API ZYM kit (bioMerieux, Lyon, France) was used to study the enzyme activity. L. plantarum JA71 was grown at $37^{\circ} \mathrm{C}$ for $18 \mathrm{~h}$ in MRS broth. Sediment from a centrifuged broth culture was used to prepare the suspension at $10^{5}-10^{6} \mathrm{CFU} / \mathrm{mL}$. After inoculation, the cultures were incubated for $5 \mathrm{~h}$ at $37^{\circ} \mathrm{C}$. The addition of a surface active agent (ZYM A reagent) in the cupules facilitated the solubilization of the ZYM B reagent in the medium. Color was allowed to develop for at least $5 \mathrm{~min}$, and values ranging from 0-5 (corresponding to the colors developed) were assigned. The approximate number for the free 
nmol hydrolyzed substrate was determined based on the color strength: 0 , negative reaction; $1,5 \mathrm{nmol} ; 2,10 \mathrm{nmol}$; 3, $20 \mathrm{nmol} ; 4,30 \mathrm{nmol} ; 5,40 \mathrm{nmol}$ or higher.

\section{Bile tolerance}

Bile tolerance was tested as described by Gilliland and Walker (1990). L. plantarum JA71 was grown at $37^{\circ} \mathrm{C}$ for $18 \mathrm{~h}$ in the MRS broth. Each $1 \%$ of L. plantarum JA71 strain culture was inoculated onto sterilized MRS broth containing $0.05 \%$ L-cysteine (Sigma) with or without $0.3 \%$ oxgall (Sigma), and then the growth potential was compared in the presence of the bile.

Then, the cultures were incubated anaerobically at $1 \mathrm{~h}$ intervals until $7 \mathrm{~h}$ at $37^{\circ} \mathrm{C}$. All pour plates were incubated anaerobically at $37^{\circ} \mathrm{C}$ for $48 \mathrm{~h}$ using the $\mathrm{BCP}$ plate count agar.

\section{pH tolerance}

$\mathrm{pH}$ tolerance was tested as described by Clark et al. (1993). Solutions of $37 \% \mathrm{HCl}$ in double-distilled water were adjusted to $\mathrm{pH}$ levels of 2.0, 3.0, and 4.0. Sterile double-distilled water ( $\mathrm{pH}$ 6.4) served as the control. 10 $\mathrm{mL}$ of each $\mathrm{pH}$ solution was transferred into sterile test tubes. $1 \mathrm{~mL}$ of stock culture containing approximately $10^{9}$ $\mathrm{CFU} / \mathrm{mL}$ of $L$. plantarum JA71 using MRS agar containing $0.05 \%$ cysteine was then transferred into each of the four $\mathrm{pH}$ solutions. The $\mathrm{pH}$ solutions containing L. plantarum JA71 were then incubated anaerobically at $37^{\circ} \mathrm{C}$, followed by intermittent plating after 1,2 , and $3 \mathrm{~h}$ to stimulate the survival of $L$. plantarum JA71 under $\mathrm{pH}$ conditions common to the human stomach. Samples from the $\mathrm{pH}$ solution were taken at 1,2 , and $3 \mathrm{~h}$ after the samples were re-suspended and subjected to serial dilutions. About $100 \mu \mathrm{L}$ of the abovementioned sample solution was spread onto the surface of the BCP plate count agar plates and incubated anaerobically at $37^{\circ} \mathrm{C}$ for $48 \mathrm{~h}$.

\section{Antimicrobial activity}

Antimicrobial activity was tested as described by Gilliland and Speck (1977). Escherichia coli KFRI 174, Salmonella Typhimurium KFRI 250, and Staphylococcus aureus KFRI 219 were obtained from the culture collection of the Korea Food Research Institute. Escherichia coli was enumerated on EMB agar (Difco), Salmonella Typhimurium on Bismuth sulfite agar (Difco), and Staphylococcus aureus on Baird parker agar (Difco). All the plates were incubated for $48 \mathrm{~h}$ at $37^{\circ} \mathrm{C}$. The control culture and associative culture were incubated for $6 \mathrm{~h}$ in a water bath at $37^{\circ} \mathrm{C}$. At the end of the incubation period, the samples were removed and placed in an ice bath until analysis. The number of CFU of pathogens per $\mathrm{mL}$ was determined using the appropriate selective medium. Percentages of inhibition were determined using the following formula:

Inhibition $(\%)=$

$\underline{(\mathrm{CFU} / \mathrm{mL} \text { in control })-(\mathrm{CFU} / \mathrm{mL} \text { in associative culture })} \times 100$ (CFU/mL in control)

\section{Statistical analysis}

The results are expressed as the mean \pm standard deviation (SD). The statistical analysis was performed with the Statistical Package for Social Sciences (SPSS, SPSS Inc., USA). The significance of the differences was analyzed by conducting a one-way analysis of variance (ANOVA) with Duncan's multiple range tests. The values of $p<0.05$ were considered statistically significant.

\section{Results and Discussion}

\section{Isolation of lactic acid bacteria}

Various kinds of home-made and domestic jeotgal and chungkuk-jang products were collected, and 190 strains were isolated as lactic acid bacteria from jeotgal and chungkuk-jang in the modified MRS medium.

\section{Selection of lactic acid bacteria producing high level of extracellular folic acid}

After being incubated in MRS broth at $37^{\circ} \mathrm{C}$ for $24 \mathrm{~h}$, six kinds of strains containing over $2.0 \mu \mathrm{g} / \mathrm{mL}$ of folic acid were selected from among 190 strains, using HPLC analysis. The six kinds of strains were incubated in MRS broth at $37^{\circ} \mathrm{C}$ and their folic acid content was analyzed at $0 \mathrm{~h}, 12 \mathrm{~h}$, and $24 \mathrm{~h}$ (Table 1). Although the level of folic acid was $0 \mu \mathrm{g} / \mathrm{mL}$ after $12 \mathrm{~h}$ of incubation, JA71 showed the highest level of folic acid, i.e., $9.03 \mu \mathrm{g} / \mathrm{mL}$, at $24 \mathrm{~h}$ of incubation compared with the other strains (See Fig. 1). Lin and Young (2000) reported that eight kinds of strainsnamely, Bifidobacterium longum B6 and ATCC 15708, Lactobacillus acidophilus $\mathrm{N} 1$ and ATCC 4356, Lactobacillus delbrueckii spp. bulgaricus 448 and 449, and Streptococcus thermophilus $\mathrm{MC}$ and 573- produced an average of $0.07 \mu \mathrm{g} / \mathrm{mL}$ folic acid after incubation for $6 \mathrm{~h}$ at $37^{\circ} \mathrm{C}$ in reconstituted non-fat dry milk, and that the level of folic acid dwindled after more than $6 \mathrm{~h}$ of incubation. Also, Sybesma et al. (2003) reported that they found the specific gene in L. latis to increase the intra- and extracellular folate production. The result of overexpression of the gene, $L$. 
Table 1. HPLC analysis of extracellular folic acid producing bacteria

\begin{tabular}{clccc}
\hline \hline Strains & \multicolumn{2}{c}{ Incubation time (hour) } & \multirow{2}{*}{ Source } \\
\cline { 2 - 4 } & 0 & 12 & 24 & Chungkuk-jang \\
\hline Enterococcus hirae C1 & 0 & 0 & 0 & Chungkuk-jang \\
Enterococcus saccharolyticus C3 & 0 & 0 & $416,567(9.03 \mu \mathrm{g} / \mathrm{mL})$ & Jeotgal \\
Lactobacillus plantarum JA71 & 0 & 0 & $410,858(8.91 \mu \mathrm{g} / \mathrm{mL})$ & Chungkuk-jang \\
Bacillus licheniformis C4 & 0 & 0 & $407,198(8.83 \mu \mathrm{g} / \mathrm{mL})$ & Chungkuk-jang \\
Bacillus subtilis C2 & 0 & $401,240(8.70 \mu \mathrm{g} / \mathrm{mL})$ & Jeotgal \\
Bacillus subtilis $\mathrm{J} 2$ & 0 & $368,620(7.99 \mu \mathrm{g} / \mathrm{mL})$ & $417,932(8.93 \mu \mathrm{g} / \mathrm{mL})$ & \\
\hline
\end{tabular}
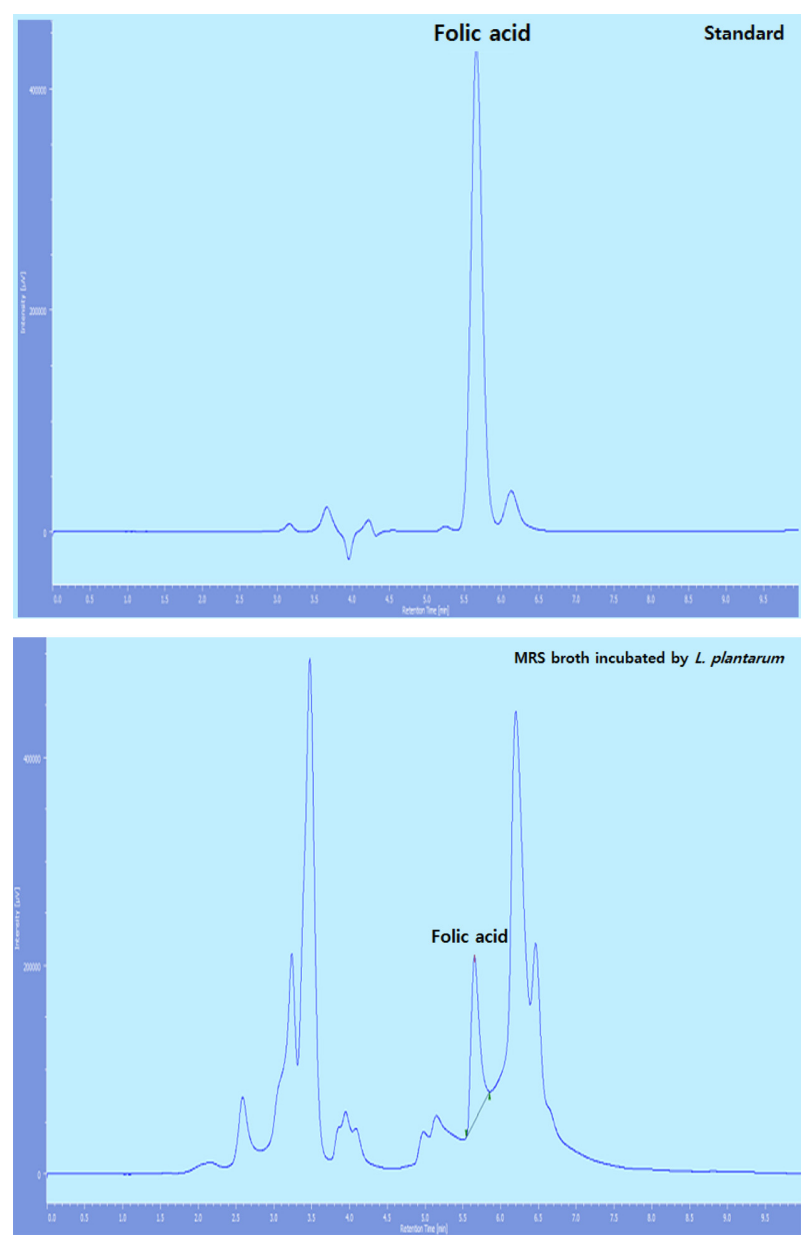

Fig. 1. HPLC analysis of extracellular folic acid of Standard (up) and MRS broth incubated by Lactobacillus plantarum JA71 (down).

latis produced $0.08 \mu \mathrm{g} / \mathrm{mL}$ of extracellular folate. As such, JA71 shows a greater capacity to produce folic acid than these other strains.

\section{Identification and DNA sequencing of the selected strain JA71}

Physiological and biochemical tests were conducted to determine the genus and species of the selected JA71 strain. The JA71 strain consisted of non-spore, rod-type, hetero fermentative, gram-positive bacteria, and exhibited
Table 2. Physiological characteristics of Lactobacillus plantarum JA71

\begin{tabular}{|c|c|c|c|}
\hline \multicolumn{2}{|c|}{ Gram reaction } & \multicolumn{2}{|l|}{+} \\
\hline \multicolumn{2}{|l|}{ Cell type } & \multicolumn{2}{|l|}{ rod } \\
\hline \multicolumn{2}{|c|}{ Spore forming } & \multicolumn{2}{|l|}{-} \\
\hline \multicolumn{2}{|l|}{ Motility } & \multicolumn{2}{|l|}{-} \\
\hline \multicolumn{2}{|c|}{ Aerobic growth } & \multicolumn{2}{|l|}{+} \\
\hline \multicolumn{2}{|c|}{ Anaerobic growth } & \multicolumn{2}{|l|}{+} \\
\hline \multicolumn{2}{|c|}{ Catalase reaction } & \multicolumn{2}{|l|}{-} \\
\hline \multicolumn{2}{|c|}{ Growth at 15} & \multicolumn{2}{|l|}{+} \\
\hline \multicolumn{2}{|c|}{ Growth at 45} & \multicolumn{2}{|l|}{+} \\
\hline \multicolumn{2}{|c|}{ Gas forming from glucose } & \multicolumn{2}{|l|}{-} \\
\hline \multicolumn{2}{|c|}{$\begin{array}{l}\text { Ammonia production from algini } \\
\text { Acid production from }\end{array}$} & \multicolumn{2}{|l|}{$\mathrm{n}$} \\
\hline Glycerol & - & Salicin & + \\
\hline Erythritol & - & D-Celiobiose & + \\
\hline D-Arabinose & - & D-Maltose & + \\
\hline L-Arabinose & + & D-Lactose & + \\
\hline D-Ribose & + & D-Melibiose & + \\
\hline D-Xylose & - & D-Saccharose & + \\
\hline L-Xylose & - & D-Trehalose & + \\
\hline D-Adonitol & - & Inulin & - \\
\hline $\begin{array}{l}\text { Methyl- } \beta \text { D-Xylo- } \\
\text { pyranoside }\end{array}$ & - & D-Melezitose & + \\
\hline D-Galactose & + & D-Raffinose & + \\
\hline D-Glucose & + & Amidon (starch) & - \\
\hline D-Fructose & + & Glycogen & - \\
\hline D-Mannose & + & Xylitol & - \\
\hline L-Sorbose & - & Gentiobiose & + \\
\hline L-Rhamnose & - & D-Turanose & + \\
\hline Dulcitol & - & D-Lyxose & - \\
\hline Inositol & - & D-Tagatose & - \\
\hline D-Mannitol & + & D-Fucose & - \\
\hline D-Sorbitol & + & L-Fucose & - \\
\hline $\begin{array}{l}\text { Methyl-aD-Manno- } \\
\text { pyranoside }\end{array}$ & + & D-Arabitol & - \\
\hline $\begin{array}{l}\text { Methyl-aD-Gluco- } \\
\text { pyranoside }\end{array}$ & - & L-Arabitol & - \\
\hline N-AcetylGlucosamine & + & Potassium Gluconate & + \\
\hline Amygdalin & + & $\begin{array}{c}\text { Potassium } \\
\text { 2-KetoGluconate }\end{array}$ & - \\
\hline Arbutin & + & $\begin{array}{l}\text { Potassium } \\
\text { 5-KetoGluconate }\end{array}$ & - \\
\hline Esculin & + & & \\
\hline
\end{tabular}

negative properties on catalase and motility. In addition, it can grow at $15^{\circ} \mathrm{C}$ and $45^{\circ} \mathrm{C}$. As it does not produce gas 


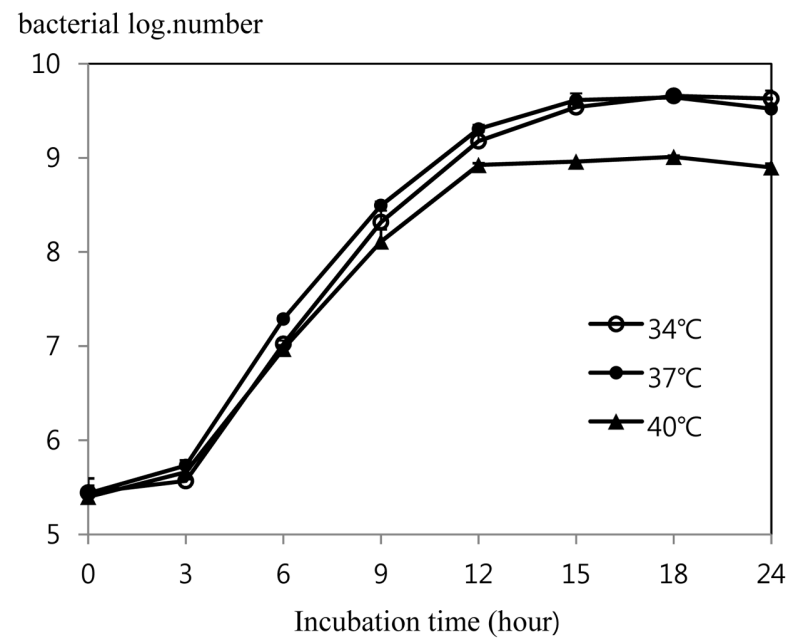

Fig. 2. Growth of Lactobacillus plantarum JA71 in MRS broth at various temperature.

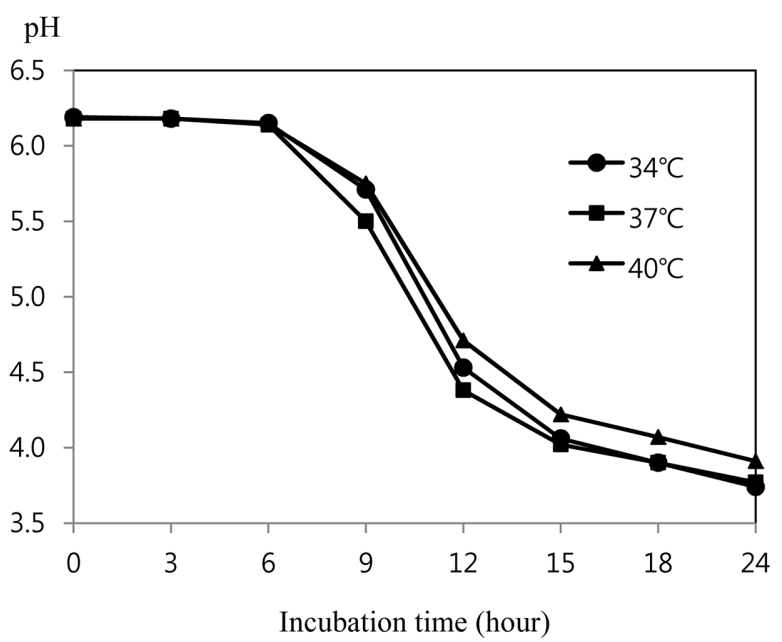

Fig. 3. pH changes of MRS broth during the growth of Lactobacillus plantarum JA71 in MRS broth at $37^{\circ} \mathrm{C}$.

and ammonia from glucose and arginine, it was identified as a genus Lactobacillus (Table 2). After PCR amplification using universal primers targeting 16S rDNA and the following sequence analysis, it was identified as Lactobacillus plantarum with similarity of $99 \%$ (data not shown). Based on the results of previous studies, it was named as Lactobacillus plantarum JA71.

\section{Growth of strain}

The number of viable $L$. plantarum JA71 was determined by serial ten-fold dilution in $0.1 \%$ peptone water. $10 \mu \mathrm{L}\left(9.6 \times 10^{5} / \mathrm{mL}\right)$ of $L$. plantarum JA71 was inoculated into $150 \mathrm{~mL}$ of MRS broth; then, the culture was incubated at $34^{\circ} \mathrm{C}, 37^{\circ} \mathrm{C}$ and $40^{\circ} \mathrm{C}$ for $24 \mathrm{~h}$, and checked at intervals of $3 \mathrm{~h}$, with the highest growth rate identified at
Table 3. Antibiotics susceptibility of Lactobacillus plantarum JA71

\begin{tabular}{lc}
\hline \hline Antimicrobal agents & $\begin{array}{c}\text { minimal inhibitory concentrations } \\
(\mu \mathrm{g} / \mathrm{mL})\end{array}$ \\
\hline Aminoglycosides & $160 \pm 0$ \\
Amikacin & $640 \pm 0$ \\
Gentamycin & $1600 \pm 0$ \\
Kanamycin & $3200 \pm 0$ \\
Neomycin* & $1600 \pm 0$ \\
Streptomycin & $160 \pm 0$ \\
\hline 3-lactams & $640 \pm 0$ \\
Penicillin-G* & $120 \pm 0$ \\
Methicillin & $320 \pm 0$ \\
Oxacillin & $30 \pm 0$ \\
Ampicillin & $480 \pm 0$ \\
\hline Gram-positive spectrum & $240 \pm 0$ \\
Bacitracin* & $100 \pm 0$ \\
Rifampicin & \\
Novobiocin & $2400 \pm 0$ \\
Lincomycin* & $80 \pm 0$ \\
\hline Gram-negative spectrum & $3200 \pm 0$ \\
Polymyxin B* & \\
\hline Broad spectrum & \\
Chloramphenicol & Vancomycin \\
\hline
\end{tabular}

*units/mL

All values are mean \pm standard deviation of three replicates.

$37^{\circ} \mathrm{C}$. The optimum growth temperature of L. plantarum JA71 was found to be $37^{\circ} \mathrm{C}$, and it took $12 \mathrm{~h}$ to reach $\mathrm{pH}$ 4.4 under this condition (Fig. 2-3).

\section{Antibiotic tolerance}

The ability to survive in antibiotic circumstances is essential when using lactic acid bacteria as probiotics (Havinaar et al., 1992). Resistance to antibiotics is attributed to the lack of cytochrome-mediated electron transport, which mediates drug and food uptake (Charteris et al., 2001). Cataloluk and Gogebaken (2004) reported that some strains belonging to Lactobacillus acidophilus, Lactobacillus crispatus, Lactobacillus gasseri and Lactobacillus plantarum show antibiotic resistance. This resistance may be obtained in the intestinal tract during passage, and may be spread to dairy products by the hands of workers during production. Table 3 shows the tolerance of the L. plantarum JA71 strain on sixteen kinds of antibiotics. In fact, $L$. plantarum JA71 showed itself to be more sensitive to bacitracin in a comparison of fifteen different antibiotics, and exhibited most resistance to neomycin and vancomycin. Their results differ from those of Danielsen and Wind (2003) and Goldstein et al. (2000). They reported that Lactobacillus is sensitive to penicillin 


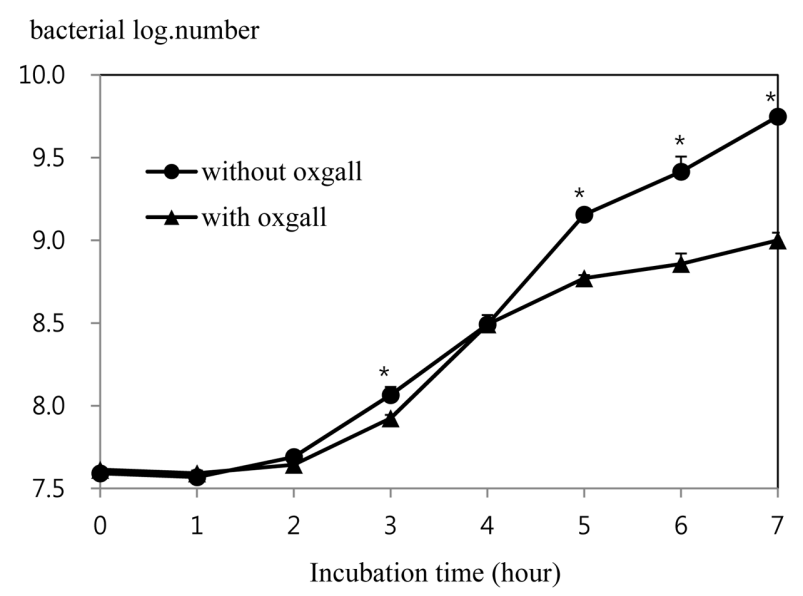

Fig. 4. Growth of Lactobacillus plantarum JA71 in MRS broth containing $0.05 \%$ L-cysteine with/without $0.3 \%$ oxgall. ${ }^{*} p<0.05$ between with oxgall and without oxgall (t-test).

and more resistant to oxacillin. However, according to the review by Mathur and Singh (2005), Lactobacillus strains show variable values of antibiotic resistance.

\section{Enzyme activity}

When using lactic acid bacteria as probiotics, enzyme activity is also an important factor. Probiotics should not produce $\beta$-glucuronidase, a toxic enzyme which has been implicated in the formation of carcinogens (Borriello et al., 2003). L. plantarum JA71 did not produce $\beta$-glucuronidase; rather, it produced such enzymes as alkaline phosphatase, esterase, esterase lipase, lipase, leucine arylamidase, valine arylamidase, crystine arylamidase, acid phosphatase, naphtol-AS-BI-phosphohydrolase, $\alpha$-galactosidase, $\beta$-galactosidase, $\alpha$-glucosidase, $\beta$-galactosidase, and $\mathrm{N}$-acetyl- $\beta$-glucosaminidase. Notably, the activities of valine arylamidase and $\beta$-glucosidase were 5 degree. The enzyme profiles of the $L$. plantarum JA71 strain were similar to those of $L$. plantarum $\mathrm{PH} 04$, which was isolated from infant feces (Nguyen et al., 2007).

\section{Bile tolerance}

The structure of bacterial membrane can be disorganized by bile salt. Therefore, bile salt tolerance is one of the essential properties for lactic acid bacteria to survive in the small intestine (Lee and Salminen, 1995; Succi et al., 2005). A $0.3 \%$ concentration of bile salt is considered the critical screen for probiotics in the human gastrointestinal tract (Gilliland et al., 1984). Fig. 4 shows the growth curves in MRS broth or MRS broth containing $0.3 \%$ bile. The log value of the population after incubation for $7 \mathrm{~h}$ without $0.3 \%$ oxgall was 9.7 , but it was 9.0 with the addi-

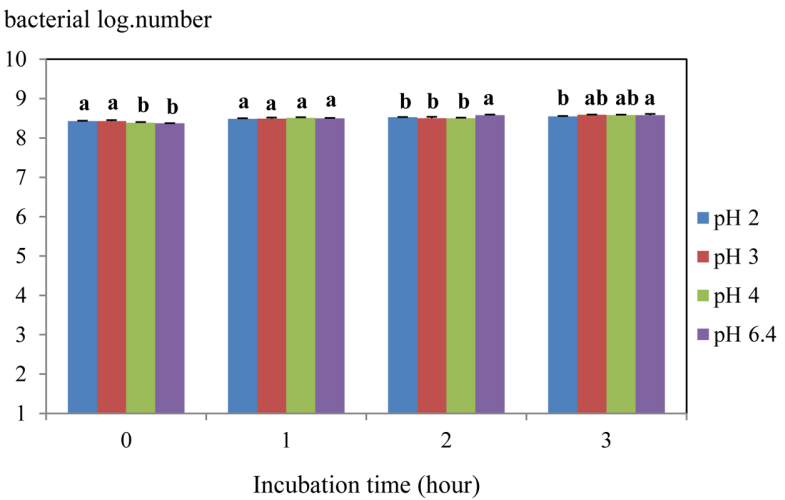

Fig. 5. Survival of Lactobacillus plantarum JA71 after $3 \mathrm{~h}$ in HCl solution (pH 2.0, 3.0, 4.0 and 6.4). ${ }^{\mathrm{a}-\mathrm{b}}$ Means values with different superscript within same time are significantly different $(p<0.05)$.

Table 4. Enzyme patterns of Lactobacillus plantarum JA71

\begin{tabular}{cc}
\hline \hline Enzyme & L. plantarum JA71 \\
\hline Alkaline phosphatase & 1 \\
Esterase (C4) & 1 \\
Esterase Lipase (C8) & 1 \\
Lipase (C14) & 1 \\
Leucine arylamidase & 4 \\
Valine arylamidase & 5 \\
Cystinearylamidase & 2 \\
Trypsin & 0 \\
$\alpha$-chymotrypsin & 0 \\
Acid phosphatase & 1 \\
$\alpha$-galactosidase & 3 \\
$\beta$-galactosidase & 1 \\
$\beta$-glucuronidase & 5 \\
$\alpha$-glucosidase & 0 \\
$\alpha$-glucosidase & 2 \\
Naphtol-AS-Bl-phosphohydrolase & 5 \\
$\alpha$-glucosaminidase & 4 \\
$\alpha$-fucosidase & 0 \\
\hline
\end{tabular}

*A value ranging from 0 to 2 is assigned to the standard color, Zero represents a negative; 5 represent a reaction of maximum intensity. Values 1 through 4 represent intermediate reactions depending on the level of intensity. The approximate activity may be estimated from the color strenght; 1 corresponds to the liberation of 5 nanomoles, 2 to 10 nanomoles, 3 to 20 nanomoles, 4 to 30 nanomoles and 5 to 40 nanomoles or more.

tion of $0.3 \%$ bile. Therefore, the survival rate of $L$. plantarum JA71 in MRS broth containing $0.3 \%$ bile was $92.8 \%$. According to Papamanoli et al. (2003), forty nine kinds of L. sakei strains, twenty kinds of $L$. curvatus strains, and seven kinds of $L$. plantarum strains were isolated during the ripening of dry fermented sausage. As a result of incubation with $0.3 \%$ bile salt, not one $L$. sakei strain survived, but $58 \%$ of the $L$. curvatus strains and all of the $L$. 
Table 5. Inhibition of pathogens by Lactobacillus plantarum JA71 in MRS broth

\begin{tabular}{|c|c|c|c|c|c|}
\hline \multirow{2}{*}{ Pathogens } & \multicolumn{2}{|c|}{ "Pathogens ${ }^{a}$} & \multicolumn{2}{|c|}{ L. plantarum K154 ${ }^{\mathrm{a}}+$ Pathogens } & \multirow{2}{*}{ Inhibition (\%) } \\
\hline & $\mathrm{CFU} / \mathrm{mL}$ & $\mathrm{pH}$ & $\mathrm{CFU} / \mathrm{mL}$ & $\mathrm{pH}$ & \\
\hline Escherichia coli & $3.3 \pm 0.2 \times 10^{7}$ & 6.6 & $1.3 \pm 0.1 \times 10^{7}$ & 4.7 & $60.4 \pm 1.9$ \\
\hline Salmonella Typhimurium & $2.9 \pm 0.2 \times 10^{7}$ & 6.5 & $9.5 \pm 0.3 \times 10^{5}$ & 4.8 & $96.7 \pm 0.2$ \\
\hline Staphyloccous aureus & $3.1 \pm 0.2 \times 10^{8}$ & 6.4 & $7.2 \pm 0.1 \times 10^{7}$ & 4.8 & $76.2 \pm 4.4$ \\
\hline
\end{tabular}

*Initial count of $L$. plantrum JA71: $5.0 \pm 0.5 \times 10^{6} \mathrm{CFU} / \mathrm{mL}$

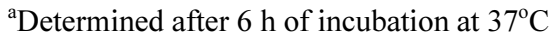

All values are mean \pm standard deviation of three replicates.

plantarum strains did survive. Thirabunyanon et al. (2009) also reported that fifty-four LAB strains were obtained from fermented dairy milk but that only four LAB strains survived in MRS broth containing $0.3 \%$ bile salt. L. plantarum JA71 has the ability of probiotics because a comparatively high percentage of the strain survived in MRS broth containing $0.3 \%$ bile salt.

\section{Acid tolerance}

Acid tolerance is a fundamental property for probiotics to survive in the gastrointestinal tract (Kirjavainen et al., 1998; Prasad et al., 1998). The $\mathrm{pH}$ of secreted $\mathrm{HCl}$ in the stomach is 0.9 . However, the $\mathrm{pH}$ value rises to $\mathrm{pH} 3$ if food is present in the stomach (Erkkila and Petaja, 2000). Therefore, it is necessary to survive with $\mathrm{pH}$ lower than 3 so that probiotics can reach the small intestine through the stomach (Booth, 1985; Mcdonald et al., 1990). Fig. 5 shows the $\mathrm{pH}$ tolerance of $L$. plantarum JA71. It showed a $94.6 \%$ survival rate after incubation for $3 \mathrm{~h}$ in highly acidic conditions ( $\mathrm{pH} 2.0$ ). According to Noriega et al. (2004), the survival rate of B. bifidum A8dOx in an acid solution $(\mathrm{NaCl} 0.5 \% \mathrm{w} / \mathrm{v}$ adjusted to $\mathrm{pH} 2.0$ with $\mathrm{HCl})$ for 90 min was $93 \%$. The value was the highest among the seventeen Bifidobacterium strains that they investigated. Pennacchia et al. (2004) reported that of the one hundred and fifty Lactobacillus strains isolated from fermented sausages, only twenty-eight strains showed a survival more than $80 \%$ at $\mathrm{pH} 2.5$ for $3 \mathrm{~h}$.

\section{Antimicrobial activity}

Lactobacillus strains' antibacterial activity derives from the production of lactic acid and other metabolites such as hydrogen peroxide and short chain fatty acids. Also, various lactic acid bacteria produce specific antibacterial compounds such as antibiotics or bacteriocins (Drago et al., 1997). Antagonism against pathogens is one of the main criteria for selecting probiotics (Ouwehand et al., 2002). According to previous studies, Lactobacillus strains have variable ability to inhibit pathogens even within a same species (Jacobsen et al., 1999; Larsen et al., 1993; Stra- hinic et al., 2007). Table 5 shows the antimicrobial activity of L. plantarum JA71 against certain pathogenic strains. The $\mathrm{pH}$ of media of pathogenic strain was 6.4-6.6 on the other hand, the $\mathrm{pH}$ of mixed strain media of pathogenic strain and L. plantarum JA71 was 4.7-4.8 due to the acid production of $L$. plantarum JA71. L. plantarum JA 71 showed resistance against $E$. coli, S. Typhimurium and S. aureus at restraint rates of $60.4 \%, 96.7 \%$, and $76.2 \%$ respectively.

\section{Conclusion}

LAB with a great folic acid production ability was isolated form jeotgal and chungkuk-jang. MRS broth was used to select the strains with folic acid-producing activity from the isolated strains. The selected JA71 strain was identified as Lactobacillus plantarum by the result of API carbohydrate fermentation test and 16S rDNA sequence. The optimum growth temperature of $L$. plantarum JA71 was found to be $37^{\circ} \mathrm{C}$, and the cultures took $12 \mathrm{~h}$ to reach $\mathrm{pH}$ 4.4. L. plantarum JA71 was able to survive in the antibiotic circumstance at a high concentration, and did not produce any carcinogenic enzymes such as $\beta$-glucuronidase.

Moreover, it was comparatively tolerant of bile juice and acid, and displayed resistance to pathogenic strains. These results demonstrate that L. plantarum JA71 could be an excellent strain for application to functional products with folic acid production.

\section{Acknowledgements}

This study was supported by a grant from the Korea Food Research Institute (project no. E0131301).

\section{References}

1. Booth, I. R. (1985) Regulation of cytoplasmic $\mathrm{pH}$ in bacteria. Microbiol. Rev. 49, 359-378.

2. Borriello, S. P., Hammes, W. P., Holzapfel, W., Marteau, P., 
Schrezenmeir, J., Vaara, M., and Valtonen, V. (2003) Safety of probiotics that contain Lactobacillus or bifidobacteria. Clin. Infect. Dis. 36, 775-780.

3. Buchanan, R. E. and Gibbons, N. E. (1974) Bergey's manual of determinative bacteriology. (ed), Waverly Press, Inc., Baltimore. pp. 576-593.

4. Cataloluk, O. and Gogebaken, B. (2004) Presebce of drug resistance in intestinal lactobacilli of dairy and human origin. FEMS Microbiol. Lett. 236, 7-12.

5. Charteris, W. P., Kelly, P. M., Morelli, L., and Collins, J. K. (2001) Gradient diffusion antibiotic susceptibility testing of potentially probiotic lactobacilli. J. Food Prot. 64, 2007-2014.

6. Clark, P. A., Cotton, L. N., and Martin, J. H. (1993) Selection of bifidobacteria for use as dietary adjuncts in cultured dairy foods: II-tolerance to simulated $\mathrm{pH}$ of human stomachs. $\mathrm{Cul}$. Dairy Prod. J. 28, 11-14.

7. Cotter, P. D., Hill, C., and Ross, R. P. (2005) Bacteriocins: developing innate immunity for food. Nat. Rev. Microbiol.3, 777-788.

8. Dangour, A. D., Whitehouse, P. J., Rafferty, K., Mitchell, S. A., Smith, L., Hawkesworth, S., and Vallas, B. (2010) B-vitamins and fatty acids in the prevention and treatment of Alzheimer's disease and dementia: a systematic review. J. Alzheimers Dis. 22, 205-224.

9. Danielsen, M. and Wind, A. (2003) Susceptibility of Lactobacillus spp. to antimicrobial agents. Int. J. Food Microbiol. 82, 1-11.

10. Divya, J. B., Varsha, K. K., and Nampoothiri, K. M. (2012) Newly isolated lactic acid bacteria with probiotic features for potential application in food industry. Appl. Biochem. Biotechnol. 167, 1314-1324.

11. Drago, L., Gismondo, M. R., Lombardi, A., Haen, C. D., and Gozzini, L. (1997) Inhibition of in vitro growth of enteropathogens by new Lactobacillus isolates of human intestinal origin. FEMS Microbiol. Lett. 153, 455-463.

12. Duthie, S. J., Whalley, L. J., Collins, A. R., Leaper, S., Berger, K., and Deary, I. J. (2002) Homocysteine, B vitamin status, and cognitive function in the elderly. Am. J. Clin. Nutr. 75, 13-908.

13. Erkkila, S. and Petaja, E. (2000) Screening of commercial meat starter cultures at low $\mathrm{pH}$ and in the presence of bile salts for potential probiotic use. Meat Sci. 55, 279-300.

14. Gilliland, S. E. and Speck, M. L. (1977) Antagonistic action of Lactobacillus acidophilus toward intestinal and foodborne pathogens in associative cultures. J. Food Prot. 40, 820-823.

15. Gilliland, S. E., Staley, T. E., and Bush, L. J. (1984) Importance of bile tolerance of Lactobacillus acidophilus used as a dietary adjunct. J. Dairy Sci. 67, 3045-3051.

16. Gilliland, S. E. and Walker D. K. (1990) Factors to consider when selecting a culture of Lactobacillus acidophilus as a dietary adjunct to produce a hypocholesterolemic effect in humans. J. Dairy Sci. 73, 905-911.

17. Goldstein, E. J. C., Citron, D. M., Merriam, C. V., Warren, Y., and Tyrrell, K. L. (2000) Comparative in vitro activities of ertapenem (MK-0826) against 1,001 anaerobes isolated from human intra-abdominal infections. Antimicrob. Agents Che- mother. 44, 2389-2394.

18. Havinaar, R., Brink, B. T., and Veid, J. H. J. I. (1992) Selection of strains for probiotic use. In: Fuller R. (ed), Chapman \& Hall, London. pp. 209-224.

19. Hur, S. H. (1996) Critical review on the microbiological standardization of salt-fermented fish product. J. Food Sci. Nutr. 25, 885-891.

20. Jacobsen, C. N., Nielsen, V. R., Hayford, A. E., Moller, P. L., Michaelsen, K. F., Paerregaard, A., Sandstrom, B., Tvede, M., and Jakobsen, M. (1999) Screening of probiotic activities of forty-seven strains of Lactobacillus spp. by in vitro techniques and evaluation of the colonization ability of five selected strains in humans. Appl. Environ. Microbiol. 65, 4949-4956.

21. Kim, H. J., Kim, H. S., Kim, K. N., Kim, G., Son, J. I., Kim, S. Y., and Chang., N. S. (2011) Relationship among plasma homocystein, folite, vitamin $\mathrm{B}_{12}$ and nutrient intake and neurocognitive function in the elderly. Korean J. Nutr. 44, 498506.

22. Kim, J. H., Rhee, Y. H., Oh, M. K., Lee, Y. K., and Shin, S. Y. (1996) $\beta$-galactosidase activity of lactobacillus spp. from pickles. J. Korean. Soc. Appl. Biol. Chem. 39, 437-442.

23. Kirjavainen, P. V., Ouwehand, A. C., Isolauri, E., and Salminen, S. J. (1998) The ability of probiotic bacteria to bind to human intestinal mucus. FEMS Microbiol. Lett. 167, 185-189.

24. Kruman, I. I., Culmsee, C., Chan, S. L., Kruman, Y., Gue, Z., Penix, L., and Mattson, M. P. (2000) Homocysteine elicits a DNA damage response in neurins that promotes apoptosis and hypersensitivity to excitotoxicity. J. Neurosci. 20, 69206926.

25. Larsen, A. G., Vogensen, F. K., and Josephsen, J. (1993) Antimicrobial activity of lactic acid bacteria isolated from sour doughs: purification and characterization of bavaricin A, a bacteriocin produced by Lactobacillus bavaricus MI401. J. Appl. Bacteriol. 75, 113-122.

26. Lee, Y. K. and Salminen, S. (1995) The coming of age of probiotics. Trends Food Sci. Technol. 6, 241-245.

27. Lin, M. Y. and Young, C. M. (2000) Folate levels in cultures of lactic acid bacteria. Int. Dairy J. 10, 409-413.

28. Mathur, S. and Singh, R. (2005) Antibiotic resistance in food lactic acid bacteria-a review. Int. J. Food Microbiol. 105, 281-295.

29. Mcdonald, L. C., Fleming, H. P., and Hassan, H. M. (1990) Acid tolerance of Leuconostoc mesenteroides and Lactobacillus casei. Appl. Environ. Microbial. 53, 2124-2128.

30. McMahon, J. A., Green, T. J., Skeaff, C. M., Knight, R. G., Mann, J. I., and Williams, S. M. (2006) A controlled trial of homocysteine lowering and cognitive performance. N. Engl. J. Med. 354, 2764-2772.

31. Morris, M. C., Evans, D. A, Bienias, J. L., Tangney, C. C., Hebert, L. E., Scherr, P. A., and Schneider, J. A. (2005) Dietary folate and vitamin $\mathrm{B}_{12}$ intake and cognitive decline among community-dwelling older perons. Arch. Neurol. 62, 641-645.

32. Nguyen, T. D. T., Kang, J. H., and Lee, M. S. (2007) Characterization of Lactobacillus plantarum $\mathrm{PH} 04$, a potential probiotic bacterium with cholesterol-lowering effects. Int. J. 
Food Microbiol. 113, 358-361.

33. Noriega, L., Gueimonde, M., Sanchez, B., Margolles, A., and Reyes-Gavilan, C. G. D. L. (2004) Effect of the adaptation to high bile salt concentrations on glycosidic activity, survival at low $\mathrm{pH}$ and cross-resistance to vile salts in Bifidobacterium. Int. J. Food Micro. 94, 79-86.

34. Ouwehand, A. C., Salminen, S., and Isolauri, E. (2002) Probiotics: an overview of beneficial effects. Antonie van Leeuwenhoek 82, 279-289.

35. Papamanoli, E., Tzanetakis, N., Litopoulou-Tzanetaki, E., and Kotzekidou, P. (2003) Characterizaton of lactic acid bacteria isolated form a Greek dry fermented sausage in respect of their technological and probiotic properties. Meat Sci. 65, 859-867.

36. Pennacchia, C., Ercolini, D., Blaiotta, G., Pepe, O., Mauriello, G., and Villani, F. (2004) Selection of Lactobacillus strains from fermented sausages for their potential use as probiotics. Meat Sci. 67, 309-317.

37. Prasad, J., Gill, H., Smart, J., and Gopal, P. K. (1998) Selection and characterization of Lactobacillus and Bifidobacterium strains for use as probiotics. Int. Dairy J. 8, 993-1002.

38. Riggs, K. M., Spiro, A., Tucker, K., and Rush, D. (1996) Re- lations of vitamin B-12, vitamin B-6, folate, and homocysteine to cognitive performance in the normative aging study. Am. J. Clin. Nutr. 63, 306-314.

39. Strahinic, I., Busarcevic, M., Pavlica, D., Milasin, J., Colic, N., and Topisirovic L. (2007) Molecular and biochemical characterizations of human oral lactobacilli as putative probiotic candidates. Oral Microbial. Immunol. 22, 111-117.

40. Succi, M., Tremonte, P., Reale, A., Sorrentino, E., Grazia, L., and Pacifico, S. (2005) Bile salt and acid tolerance of Lactobacillus rhamnosus strains isolated from Parmigiano Reggiano cheese. FEMS Microbiol. Lett. 244, 129-137.

41. Sybesma, W., Starrenburg, M., Kleerebezem, M., Mierau, L., De Vos, W. M., and Hugenholtz, J. (2003) Increased production of folate by metabolic engineering of Lactococcus lactis. Appl. Environ. Microbiol. 69, 3069-3076.

42. Thirabunyanon, M., Boonprowom, P., and Niamsup, P. (2009) Probiotic potential of lactic acid bacteria isolated from fermented dairy milk on antiproliferation of colon cancer cells. Biotechnol. Lett. 31, 571-576.

(Received 2013.10.31/Revised 2014.1.27/Accepted 2014.1.28) 